\title{
ACTIVATION OF LEFT INTRAPARIETAL SULCUS USING A FMRI CONCEPTUAL PRAXIS PARADIGM
}

\author{
JORGE MOLL *, RICARDO DE OLIVEIRA-SOUZA**, \\ FABIANA DE SOUZA-LIMA*, PEDRO ANGELO ANDREIUOLO***
}

\begin{abstract}
The present paper reports the results of a fMRI subtraction study of the pattern of cortical activation induced by an ideational praxis paradigm in six normal right-handed subjects. The control task consisted of a sequence of complex meaningless hand movements. A complete study was done for each hand in each subject. The left intraparietal sulcus was the only structure activated in all subjects regardless of the hand used in the task. These findings, albeit preliminary, suggest that the organization of actions involving the mediation of tools and utensils are strongly lateralized to the left hemisphere and that damage to the dominant intraparietal sulcus may be critical for the development of the clinical syndrome of conceptual apraxia.
\end{abstract} imaging.

KEY WORDS: conceptual apraxia, intraparietal sulcus, cerebral asymmetry, functional magnetic resonance

\section{Ativação do sulco intraparietal esquerdo utilizando RMf e um paradigma de praxis conceitual}

RESUMO - No presente artigo, reportamos os resultados de RMf da ativação cortical induzida por um paradigma de praxis de uso de ferramentas em seis pessoas dextras normais. A tarefa-controle consistiu de uma sequência de movimentos unimanuais complexos, mas desprovidos de significado. Um estudo completo de pantomima e controle foi feito para cada mão. O sulco intraparietal esquerdo foi a única estrutura ativada em todos os indivíduos, independentemente da mão utilizada. Esses achados, embora preliminares, indicam que a organização de ações mediadas por ferramentas e utensílios são fortemente lateralizadas para o hemisfério esquerdo nas pessoas normais, e sugerem que lesões na região do sulco intraparietal do hemisfério dominante são críticas para o aparecimento de apraxia conceitual. funcional.

PALAVRAS-CHAVE: apraxia conceitual, sulco intraparietal, assimetria cerebral, ressonância magnética

Conceptual apraxia (CA) is the inability to select and use tools and utensils despite normal sensation, motor power, and coordination ${ }^{1-4}$. Patients with CA are at a loss when they attempt to use a screwdriver, unlock a padlock, or cut bread with a knife. At times they look so bewildered when faced by such everyday tasks that they may be erroneously diagnosed as demented. The correlates of CA have been poorly defined, largely because the available post-mortem studies have been done on patients with a variety of diffuse or multifocal brain diseases ${ }^{5,6}$. Most authors would assent, however, that $\mathrm{CA}$ is related to the dominant inferior parietal lobule ${ }^{5,7}$. Moreover, the few cases of CA without dementia on record offer some evidence that CA results from damage to a neural system engaged in tool-mediated actions which is independent, to a large extent, of language, gnosis, and selective attention ${ }^{8}$. Since the anatomical correlates of CA in such cases have pointed to more than

*Labs - Exames Complementares and Universidade Federal do Rio de Janeiro (UFRJ); **Universidade do Rio de Janeiro (UNI-Rio) and Instituto Philippe Pinel, Rio de Janeiro; ***Labs - Exames Complementares. Aceite: 12-setembro-1998.

Dr. Ricardo de Oliveira Souza - Rua General Belford 226 - 20961-000 Rio de Janeiro RJ - Brasil. 
one site ${ }^{5,9}$, reliable conclusions regarding the critical regions which must be damaged in order to CA for manifest itself clinically cannot be drawn. For similar reasons, the brain circuits involved in the generation of transitive actions in normal individuals remain poorly specified.

In the present paper, we report our preliminary functional magnetic resonance imaging (fMRI) findings on tool-use behavior in normal subjects.

\section{METHODS}

\section{fMRI acquisition and analysis}

Dynamic T2* echo-planar images were acquired with a $1.5 \mathrm{~T}$ scanner through ten oblique planes during eight alternating task and control periods. Imaging parameters were the following: TE/TR/FLIP $=40 \mathrm{~ms} / 3000 \mathrm{~ms} /$ $90^{\circ}$, slice thickness $5.0 \mathrm{~mm}$, with no gap between slices. These parameters allow for excellent susceptibilityweighting and strongly reduce signal contribution from the macrovasculature and inflow-related effects. Activation maps were generated by cross-correlation analysis employing p-values $<0.01$. Each set of 960 images obtained during 96 time-points was acquired in a single run, and one run was obtained for each hand. A four-minute pause mediated each acquisition, during which the subjects remained still in the scanner. Scans were visually inspected for gross head movements with cine-loop and for band-like artefacts. Cluster analysis was employed in the postprocessing treatment of the images to increase specificity. Three significant activated neighbouring pixels were set as the threshold.

\section{Task-subtraction paradigm}

During task periods, 6 right-handed normal subjects pantomimed the use of 18 common tools and utensils with the right and left hand. Examples of imagined test-objects included a knife, a hammer, and a lighter. The control task consisted of a complex sequence of overlearned, meaningless, hand movements. Control activation was subtracted from pantomime activation to wipe out the areas related to real movements and optimize visualization of areas more closely related to the praxic ideation proper.

\section{RESULTS}

All scans were of good technical quality on unarmed visual inspection with cine-loop. The left intraparietal sulcus was the only area activated in all subjects, regardless of the hand employed in the task. The most significant stimulus and signal correlations were observed in the left intraparietal sulcus area. In two subjects the intraparietal sulcus of the right hemisphere was also activated. The Figure depicts a typical result of the fMRI subtraction study in one subject.

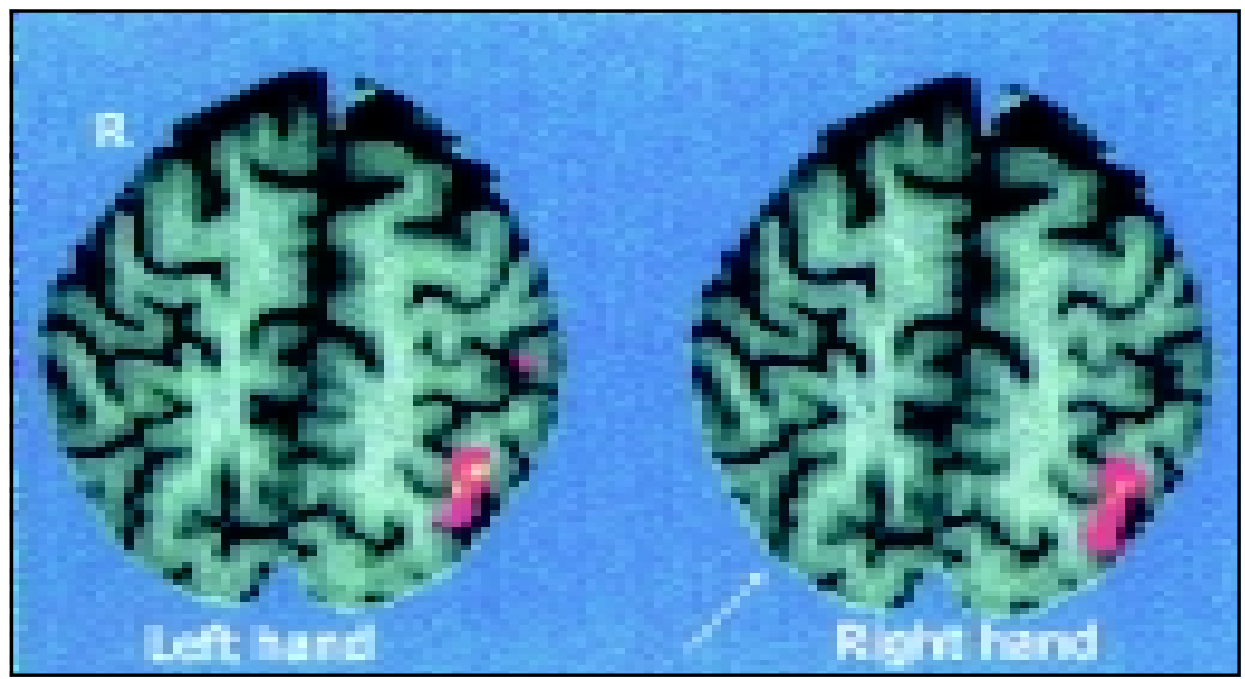

Figure. Typical result of the fMRI subtraction study in one subject. Arrow: intraparietal sulcus. 


\section{DISCUSSION}

Before discussing our results, a few caveats may be worthy of note. First, fMRI does not detect activations in the white matter. Moreover, for reasons which are still unclear, fMRI of subcortical nuclei, such as the thalamus or the basal ganglia, is not as reliable as fMRI of the cerebral cortex ${ }^{10}$. Thus, we concentrated on the cortical activations in the present analyses. Second, although we made reference to the clinical syndrome of apraxia, our study focused on normal individuals. Thus, it is not our purpose to review the mechanisms of apraxia in any depth. Nevertheless, a word of caution concerning the current usage of the term "apraxia" may be opportune. Unless otherwise specified, "apraxia" has been tacitly employed in the literature to refer to ideomotor apraxia, in Liepmann's original sense ${ }^{1}$. We believe that the mechanisms underlying the kind of praxis that we investigated are distinct from ideomotor praxis in critical aspects, for the single fact that we deliberately searched for the pattern of brain activation associated with the use of tools. That means that we did not investigate activations related to performing intransitive gestures on command or imitation, for example, which are classical methods of testing for apraxia. Thus, no a priori generalizations concerning apraxias other than those which directly affect the handy use of tools should be drawn from our results. Finally, many cortical areas which are expected to participate in complex hand movements either with or without tools may not have been visualized because they may be active in both kinds of actions which were requested in our paradigm. Since we employed a task-subtraction technique, many areas were probably wiped out. That might explain, for example, why the medial frontal lobe, an important node in the praxis circuitry ${ }^{11}$, was not activated as regularly as the intraparietal sulcus. On the other hand, the very fact that the intraparietal sulcus was powerfully activated after all subtractions had been computed is perhaps the strongest evidence that it harbors a neural circuitry which may be essential for tool-using behavior.

Our data reconcile many discrepancies and add new insights into the classical formulations of CA as well as of the cerebral organization of conceptual praxis in normal people. Based on these preliminary results, we propose that the intraparietal sulcus is critical for the breeding of ideas underlying tool-mediated actions. The intraparietal sulcus (arrow, in the Figure) is usually a continuation of the inferior postcentral sulcus. After separating the superior from the inferior parietal lobule, it arches towards the occipital lobe and adopts a more vertical and slightly medial course, separating the parietal from the occipital lobe ${ }^{12}$. The cortex buried in the sulcus is cytoarchitectonically heterogeneous ${ }^{14}$. Projections from this area are conveyed to the anterior forebrain by the superior longitudinal fasciculus, which courses beneath the inferior parietal lobule ${ }^{12,13}$. The intraparietal sulcus was never clearly advocated as critical for the generation of the idea underlying transitive actions in normal subjects. In fact, analyses of patients with focal cerebral damage implicate the inferior parietal lobule or the temporoparietal transition as a major correlate of $\mathrm{CA}^{1,5,9}$. Nevertheless, a few cases on record point to the occipitoparietal transition as essential for the development of CA. For example, out of 20 patients with CA due to lesions in a variety of locations in the left hemisphere, the single one with damage to the occipitoparietal transition also had the most severe $\mathrm{CA}^{9}$.

Although our paradigm activated both intraparietal sulci in some subjects, the intraparietal sulcus on the left side was always activated regardless of the hand used. Such findings provide direct evidence for hemispheric specialization of another non-linguistic neuropsychological human ability. They may also shed some light on clinical paradoxes, such as dissociations in the presentation of apraxia, or the absence of lasting apraxia in posterior lesions of the dominant hemisphere due to compensation by the opposite hemisphere ${ }^{15}$.

Recently, Heilman et al. showed that the left hemisphere is dominant for CA in a sample of patients with lateralized brain lesions ${ }^{16}$. However, the exact anatomic correlates of conceptual apraxia in their patients could not be determined. We believe that the findings of the present investigation contribute an important piece to this conundrum by calling attention to the possible role of the left intraparietal sulcus as a critical area involved in the genesis of apraxia for tool use. The hypothesis 
that the distinct domains of conceptual praxis described by Ochipa et al. ${ }^{3}$ are differentially distributed in spatially discrete cortical areas can be put to test in the foreseeable future.

Acknowledgements - The authors are deeply indebted to Dr. Jorge Moll Filho, whose keen foresight and open-mindedness have been a continuous source of inspiration and enthusiasm.

\section{REFERENCES}

1. Liepmann H. The left hemisphere and action. In Kimura D (ed). Translations of Liepmann's essays on apraxia. London, Ontario. DK Consultants $1980: 17-50$.

2. Ochipa C, Rothi LJG, Heilman KM. Ideational apraxia: a deficit in tool selection and use. Ann Neurol 1989;25:190-193.

3. Ochipa C, Rothi LJG, Heilman KM. Conceptual apraxia in Alzheimer's disease. Brain 1992;115:1061-1071.

4. Tranel D, Damasio AR. Agnosias and apraxias. In Bradley W.G., Daroff R.B., Fenichel G.M., Marsden C.D. (eds). Neurology in Clinical practice, volume I: Principles of diagnosis and management. 2.Ed. Boston: Butterworth-Heinemann, 1996:119-129.

5. De Ajuriaguerra J, Hécaen H, Angelerges R. Les apraxies: varietés cliniques et latéralisation lésionnelle. Rev Neurol (Paris) 1960;102:28-57.

6. Heilman KM, Rothi LJG. Apraxia. In: Heilman K.M., Valenstein E., (eds). Clinical neuropsychology, 3.Ed. New York: Oxford Univ Press 1993:141-163.

7. Poeck K. Ideational apraxia. J Neurol 1983;230: 1-5.

8. Ochipa C, Rapcsak SZ, Maher LM, Rothi LJG, Bowers D, Heilman KM. Selective deficit of praxis imagery in ideomotor apraxia. Neurology 1997;49:474-480.

9. De Renzi E, Lucchelli F. Ideational apraxia. Brain 1988; 111:1173-1185.

10. Buchbinder BR, Cosgrove GR. Cortical activation in MR studies in brain disorders. MRI Clin North Am 1998;6:67-93.

11. Watson RT, Fleet WS, Rothi LJG, Heilman KM. Apraxia and the supplementary motor area. Arch Neurol 1986;43:787-792.

12. Curnes JT, Burger PC, Djang WT, Boyko OB. MR imaging of compact white matter pathways. Am J Neuroradiol 1988;9:1061-1068.

13. Dejerine J. Anatomie des centres nerveux, Tome I. Paris: Rueff et Cie., 1895.

14. Watson RT, Valenstein E, Day A, Heilman KM. Posterior neocortical systems subserving awareness and neglect. Arch Neurol 1994;51:1014-1021.

15. Rapcsak SZ, Ochipa C, Beeson PM, Rubens AB, Labadie EL. Praxis and the right hemisphere. Neurology 1991;41 (Suppl. 1):409.

16. Heilman KM, Maher LM, Greenwald MI, Rothi LJG: Conceptual praxis from lateralized lesions. Neurology, 1997; 49: 457-464. 